\title{
Debris-flow functioning and their contribution to sedimentary budgets: the Peynin subcatchment of the Guil River (Upper Queyras, Southern French Alps)
}

\author{
Vincent Viel ${ }^{1 *}$, Monique Fort $\odot ~ 1$, Candide Lissak², Kevin Graff², Benoît Carlier ${ }^{1}$, \\ Gilles Arnaud-Fassetta' ${ }^{1}$, Etienne Cossart ${ }^{3}{ }^{3}$, Malika Madelin' \\ 'Department of Geography, UFR GHES, Université Paris-Diderot (Paris 7), Paris, France, *vincent.viel@univ-paris-diderot.fr \\ 2Department of Geography, UFR SEGGAT, Université Caen Normandie, Caen, France \\ ${ }^{3}$ Department of Geography and Management, Université de Lyon (Jean Moulin Lyon 3), Lyon, France
}

\begin{abstract}
The Peynin catchment $\left(15 \mathrm{~km}^{2}\right)$ is prone to catastrophic floods (June 1957 - Recurrence Interval R.I.>100 yr), June 2000 (R.I.-30 yr) with serious damages to infrastructure and buildings located at the outlet. In this paper, PIT tags tracers and Vensim modelling software are used to better assess the sediment delivery unsteadiness, and more specifically to evaluate the respective role of geomorphological processes on sediment supply during flood event. For the last 20 years, our results highlight a significant variability in sediment delivery from a tributary to another one. According to our studies, we suppose that two torrential tributaries of the Peynin river, the Peyronnelle and Three Arbres subcatchments $\left(<2 \mathrm{~km}^{2}\right.$, representing $<15 \%$ of the Peynin catchment area) are responsible of $80 \%$ of the sediments observed at the outlet of the catchment. Several processes take a part of these sediment transfers, but the efficiency of the sediment cascade in this catchment can be explained by a strong connectivity between sediment erosion area and the main channel of the catchment. Debris and torrential flows triggered during high intensity meteorological event are actually effectively coupled in space and time and guarantee an important sediment supply able to reload the downstream part of the sediment cascade. Recent climate trends, marked by extremes, suggest consequently more damaging events to come, in a context of increasing vulnerable assets.
\end{abstract}

Keywords: debris flow, passive integrated tracers, modelling, connectivity, environmental change, Southern French Alps

\section{Introduction}

Characterized by steep topographic, climatic and biological gradients combined with sharp seasonal contrasts, mountain environments appear as very sensitive to climate change (Beniston 2003, 2005, IPCC 2012, Beniston, Stoffel 2013, Fort 2015). They can be affected by any change in temperature and precipitation patterns that may result in increasing natural hazards and risks for the population living downstream (Grandjean et al. 2018). This is particularly true in first order catchments, where the control parameters of the torrential functioning (slopes, rocks, inherited debris storages, vegetal cover, etc.) influence directly the colluvial-alluvial interactions, hence the sediment cascade (Caine 1974). This includes the sediment budget and its dynamics, i.e. the linkages between the different sediment stores (Slaymaker 1977, Jordan, Slaymaker 1991, Slaymaker 2003, Cossart, Fort 2008), hence the modes of debris transport, and indirectly the impacts of the hydrological system at a larger scale (Brardinoni et al. 2015, Heckmann et al. 2016).

Here we consider a subcatchment located in Queyras (Southern French Alps), an area characterized by rather high denudation rates in relation with the schist bedrock supplying an abundant, fine and coarse sediment load. We try to assess the role of such 
a catchment in the sediment cascade and in the connectivity with adjacent mountain slopes. Our objective is to better understand the sediment delivery unsteadiness, and more specifically to evaluate the respective role of water and sediment supply on flood characteristics. For this, and in the frame of the research project on Society Adaptation for coping with Mountain risks in a global change COntext (SAMCO), we selected the more representative and active tributary catchment of the Upper Guil: the Peynin catchment $\left(\approx 15 \mathrm{~km}^{2}\right)$. We actually focused on the Peyronnelle mountain channel, a first order, subcatchment of the Peynin torrential stream, where we estimated, mapped and quantified temporary sediment storages, and carried a preliminary analysis of functional (i.e. process-based) connectivity, so that we could estimate the respective role of threshold and processes frequencies in the sediment response of the catchment. Finally, we discuss the volumes of sediments produced by weathering and debris flow transport in the Peynin catchment for the last 20 years, and try to discuss the recent climate trends, marked by an increase in extreme events, with probably more damaging events to come, in a context of increasing vulnerable assets.

\section{Study area}

\section{The upper Guil catchment}

Nowadays nearly entirely deglaciated, the upper Guil catchment (Queyras - $317 \mathrm{~km}^{2}$ ), a left bank tributary of the Durance River, is located in the southern French Alps, adjacent to the Italian border northwest of Mt. Viso (3841 m a.s.1.) (Fig. 1B). This sub-Mediterranean area is characterized by elevations range from $897 \mathrm{~m}$ to over $3300 \mathrm{~m}$ a.s.l., with an average relief not exceeding $1500 \mathrm{~m}$. This catchment has a long record of catastrophic floods (Arnaud-Fassetta et al. 2005, Arnaud-Fassetta, Fort, 2014), among which those of June 1957 (Recurence Interval R.I. >100 yr), considered as the reference flood (Tricart 1958), and June 2000 (R.I.-30 yr) were particularly destructive (Fig. 2). Characterized by huge sediment transport from tributaries to the main valley, highly facilitated by a strong hillslope-channel connectivity, their torrential nature is chiefly controlled by the climatic and lithostructural characteristics of the catchment.

The underlying substratum (general west-northwest dip of the Alpine thrust sheets) controls the

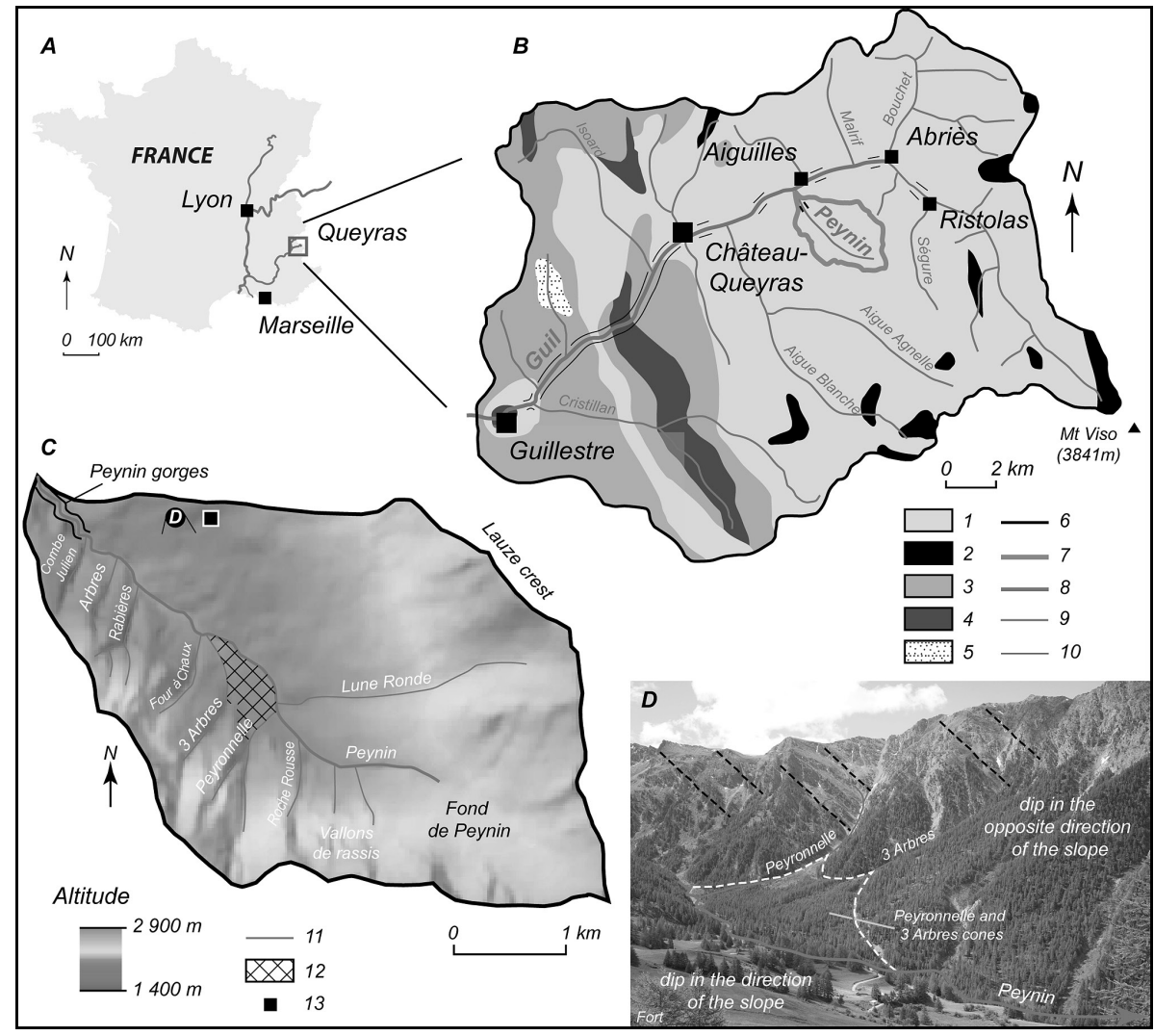

Fig. 1. The Guil River catchment

A - General location and location of the Guil basin in the Durance catchment; B - The study site corresponds to the part located upstream from Château-Queyras; Lithology: 1 - schists lustrés Q, 2 - ophiolite complex, 3 - limestones and dolomites, 4 - sandstones and conglomerates, 5 - flyschs; Hydrography: 6 - limit of the Guil catchment (317 km² upstream from Château-Queyras), 7 - limits of the Peynin catchment $\left(\right.$ area $\left.=15 \mathrm{~km}^{2}\right), 8$ - Guil River, 9 - main tributaries of the Guil River, 10 - gorge section; C - Description of the Peynin catchment: 11 - stream network, 12 - Peynin and 3 Arbres cones, 13 - Location of meteorological station; D - Overview of the left slope of the Peynin catchment, with large sediment stores of the Peyronnelle and Trois Arbres torrential fans (Photo: M.Fort) 

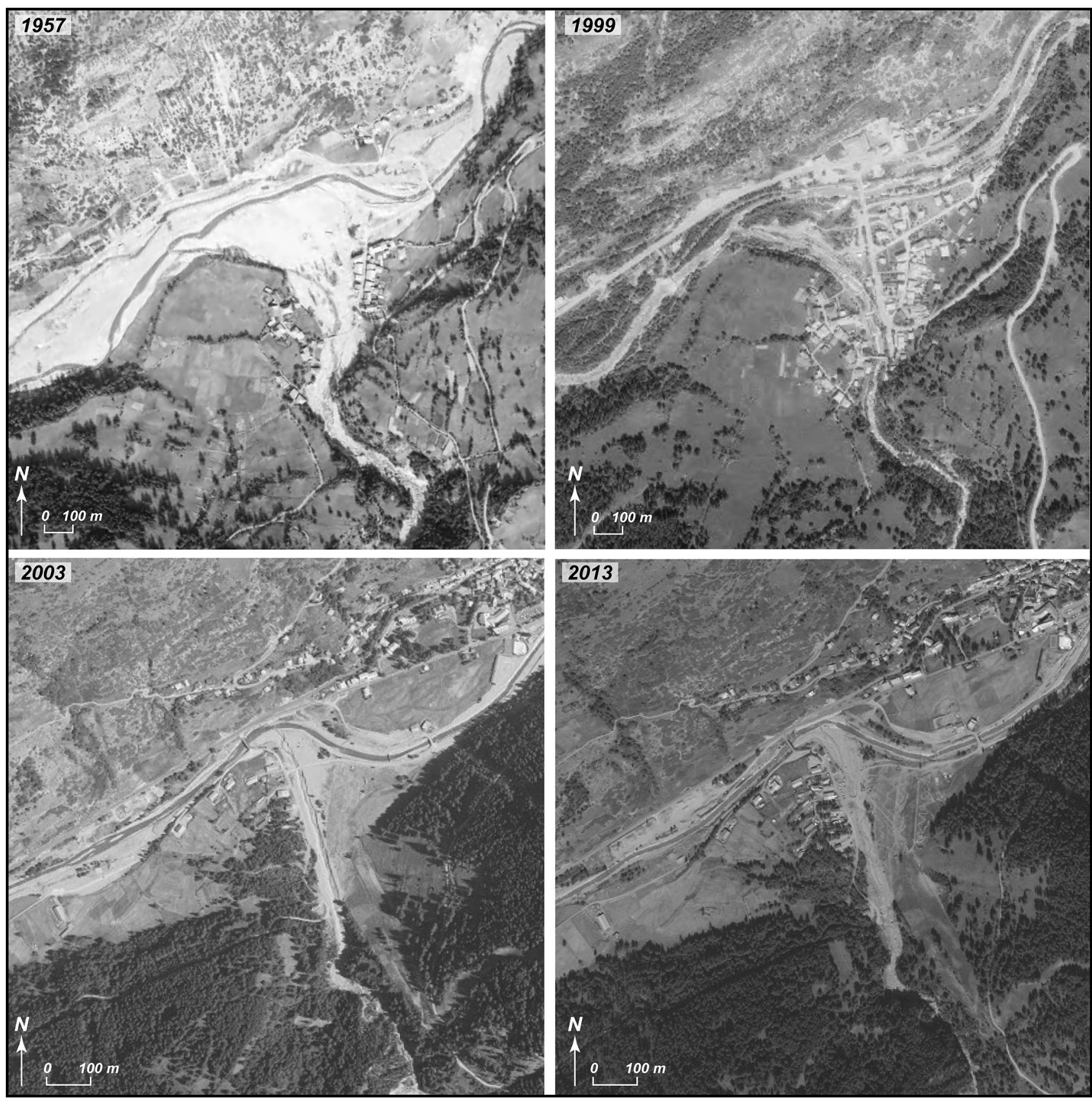

Fig. 2. The Peynin torrential cone at the junction with the Upper Guil River, downstream from Aiguilles village: orthophotos of 1957, 1999, 2003 and 2013 with impacts of the 1957 and 2000 floods (Source: IGN, Geoportail)

Note the situation of the Peynin cone after the R.I.>100 y 1957 flood, and after the R.I.-30 y 2000 flood, and the significant changes in land use (development of industrial park and ski lifts) during these periods

hydrographic network and its generally rectangular pattern (Tricart et al. 2004). The asymmetrical structural slopes (Fig. 1) are related to the late Alpine reverse folding of the Pennine nappes (Tricart 1980, Lemoine et al. 2000). Northwest, gentle dip slopes, generally deforested, are covered by a regolithic mantle and are subject to superficial translational landslides (Arnaud-Fassetta et al. 2005, Carlier et al. 2018a). These slopes contrast with the steep, rocky, northeast to southeast facing counter-dip slopes (>50\% slope), covered by larch forests and densely dissected by mixed avalanche/torrent tracks. Subdi- vided by small, first-order catchments with areas of less than $1 \mathrm{~km}^{2}$, these mountain slopes are prone to accelerated runoff with a short hydro-geomorphic response time following intense rainfall (Fort et al. 2002, Arnaud-Fassetta et al. 2005). The upper Guil is characterized by its lithology composed of $90-95 \%$ of shales, actually the schistes lustrés (Fig. 1b), supplying the riverbed in a large amount of fine sediment and coarser, small clasts. Only limited ophiolitic bedrock (Inner Alps) provides large blocks that appear as good tracers as they outcrop in the very upper part of a few catchments. 
The Guil river regime is controlled by spring snowmelt, together with localized and short rainfall storm spells (known locally as Lombarde strikes), susceptible to trigger high magnitude/low frequency flash-flood events (Tricart 1958, 1961, Fort et al. 2002). For instance, according to Arnaud-Fassetta et al. (2005), the Guil discharge was estimated to be $180 \mathrm{~m}^{3} \mathrm{~s}^{-1}$ in Aiguilles during the June 2000 event, for an annual mean discharge of $6 \mathrm{~m}^{3} \mathrm{~s}^{-1}$ (estimated specific stream power from 71 to $276 \mathrm{~W} \mathrm{~m}^{-2}$ ). The sediment load in the main channel of the Guil River mostly derives from small torrential tributaries such as the Peynin catchment (Fig. 1b), where the operating mode of transport is either hyper-concentrate flows or debris flows.

\section{The Peynin catchment and its active tributary, the Peyronnelle subcatchment}

In this study, we selected the Peynin catchment (15 $\mathrm{km}^{2}$ ), one of the most active among the left bank tributaries of the upper Guil River because it pre- sents all the predisposing factors as mentioned above:

- dissymmetrical, steep mountain slopes (Figs 1c, 3),

- high production of debris due to the schist lithology, dense tectonic jointing and efficient frost-shattering, and

- active geomorphic processes such as recurrent snow avalanches, and rainstorms-induced floods.

Its Peyronnelle, left-bank tributary subcatchment $\left(1 \mathrm{~km}^{2}\right)$ appears as one of the best sites to implement continuous monitoring of torrential activity.

The Peynin catchment is affected by a number of geomorphic processes, rather common in high mountain environments (Fig. 1D). In the upstream cirques of the basin, rock falls represent the dominant process. The extensive scree slopes they have built are subject to reworking, either as solifluction lobes (Fig. $3 \mathrm{~A}$ ), debris flow or landslides (Einhorn 2003, Carlier et al. 2018a). In spring time, slab avalanches are controlled by the regular, flat surfaces of the scree
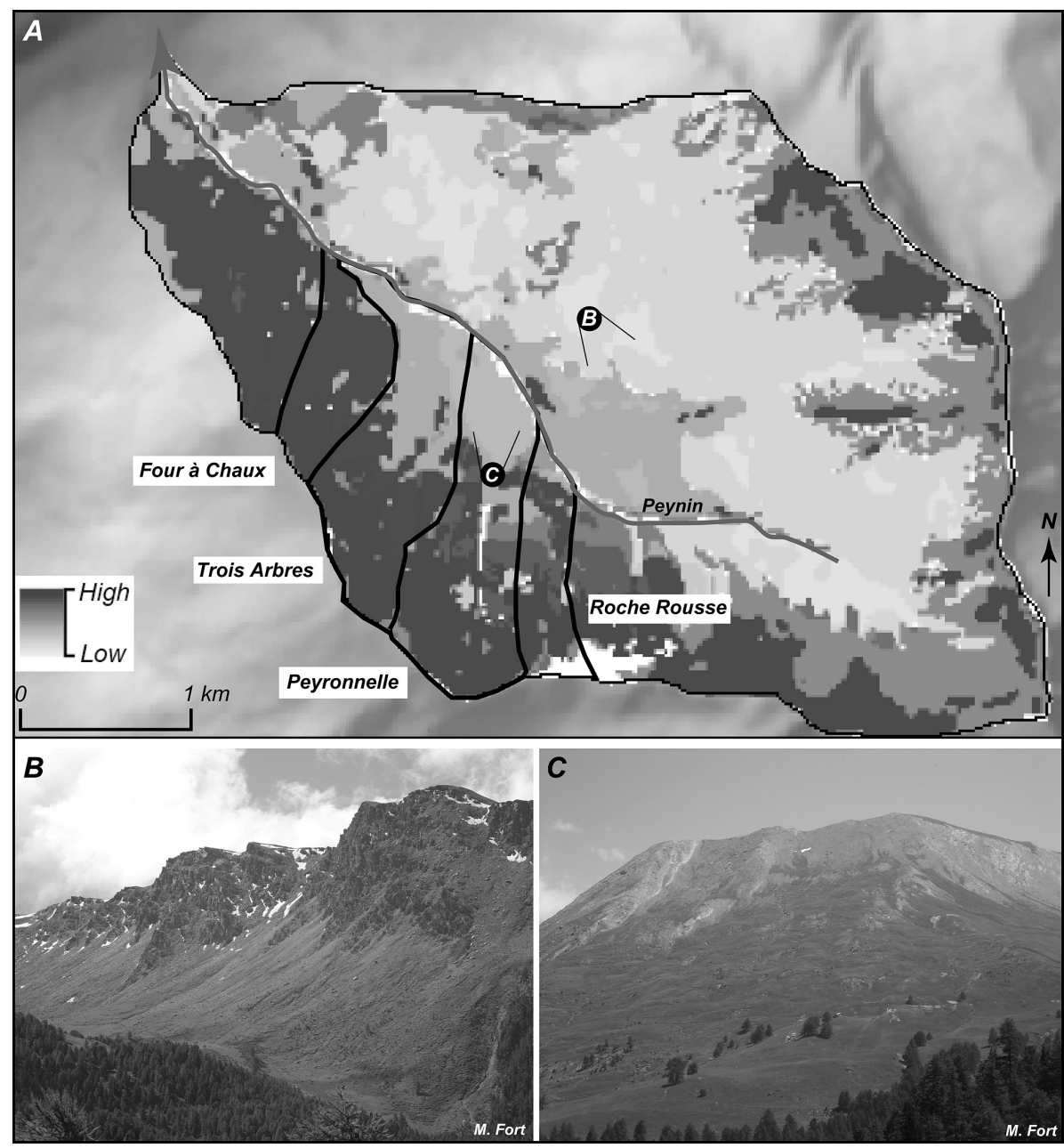

Fig. 3. The Peynin catchment

A - a map showing the contrasted slope contribution to sediment supply in the Peynin catchment in relation to the structural asymmetry and contrasts in slope processes (Lissak et al. 2015); the letters B and C refer to the photos below and the view points where they have been taken from; B - upper catchment, counter-dip slopes with solifluction lobes, and debris flow functioning, left bank of the Peynin; C - middle catchment dip-slopes with planar landslides and local slumps, right bank of the Peynin (Photos: M.Fort) 
slopes. Despite of the large volumes of debris stores, the contribution of the upstream part of the basin to the solid transport of Peynin remains quite limited because the flows are diffuse, not enough concentrated inducing a low connectivity of the sediment stores (Koulinski 2000).

Downstream of the Fond de Peynin cirque, the dominant processes differ from one side to the other side of the valley (Carlier et al. 2018a). On the right, dip-slopes of the valley, landslides and creeping are predominant processes (Fig. 3B). Large translational slides, whose scars are visible below the ridges, slowly but inexorably carry large volumes of sediment and rocks towards the foot of the slope. These slide deposits are reworked by numerous, local rotational slips and are subject to active solifluction, as attested by a bumpy topography, cattle-induced small terraces, and the local presence of drunken forests. When affected by intense rainfall, this material tends to be removed by small mudslides (extreme event such as the 1957's crisis). At the foot slope, the Peynin cuts through this colluvium material (bank erosion), hence contributing to maintain a general slope destabilization. As a result, up slopes landslides are progressively encroaching towards the crest ridge due to regressive erosion.

In contrast, the steep, counter-dip left slopes of the Peynin valley are mainly affected by processes related to hydro-gravity runoff, as attested by the many gullies that streak them (Graff et al. 2016, Carlier et al. 2018a). The torrent activity is efficient throughout most of the year, hence contributing to the many debris cones built downstream at the junction with the Peynin. More specifically in spring, heavy snow avalanches develop frequently along gullies, hence dragging sediments and vegetal debris before dropping them on the cones or in the valley bottom. Under specific conditions related to Lombarde meteorolog-

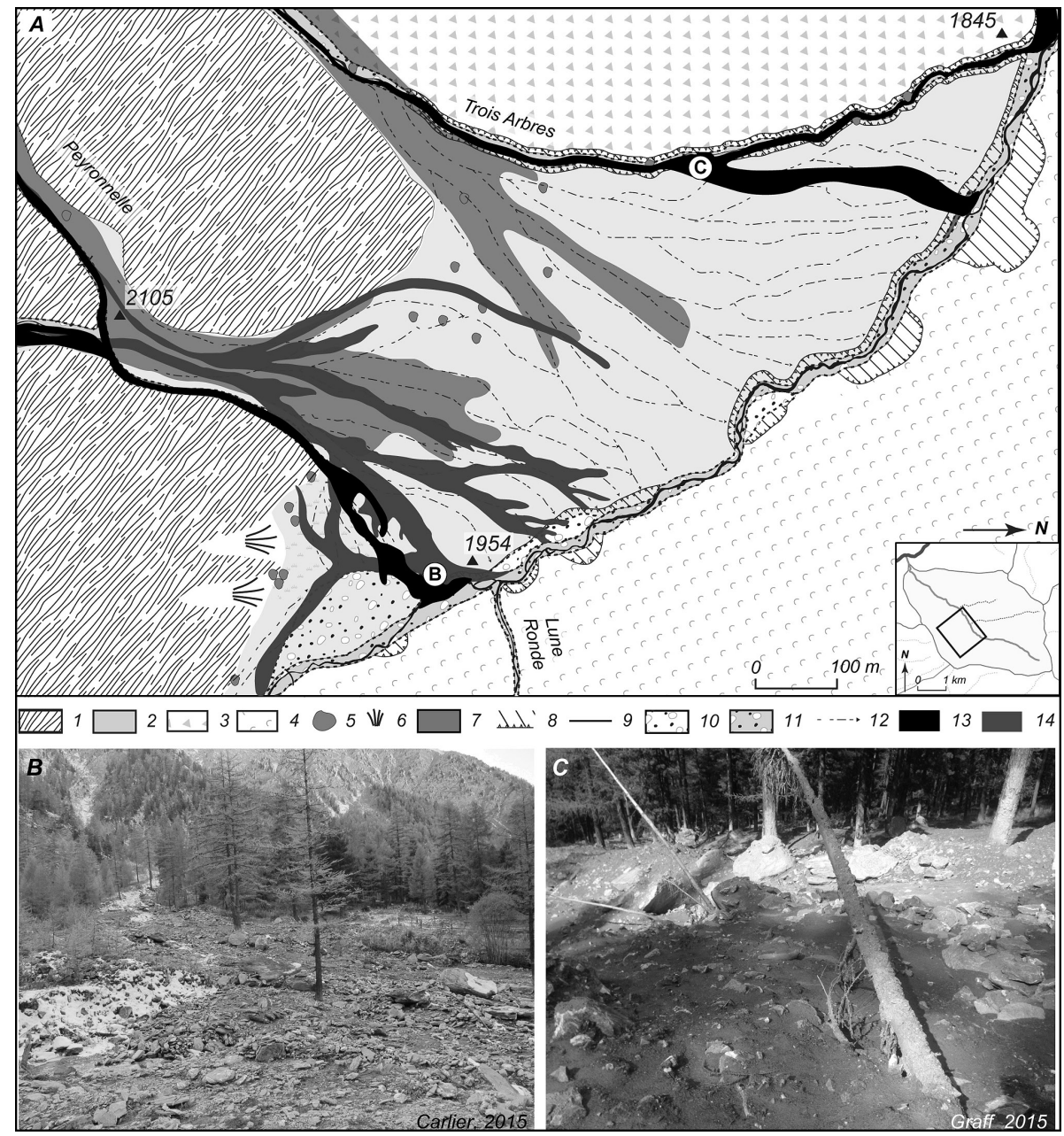

Fig. 4. Geomorphology of the downstream Peyronnelle and Trois Arbres fans as mapped after the August 2015 debris flow (updated from Graff et al. 2018, from Einhorn 2003 and Fort et al. 2002)

A - geology and processes: 1 - schist wall, 2 - alluvial fan, 3 - rock fall deposits, 4 - landslide, 5 - significant boulder, 6 - avalanche fan, 7 - avalanche deposits, 8 - fluvial scarp; hydrology: 9 - river, 10 - fluvial terrace (2000), 11 - river bed; debris flow: 12 - old debris flow tracks, 13 - August 2015 debris flow deposits, 14 - June 2000 debris flow deposits; B - August 2015 debris flow track, downstream of the Peyronnelle fan, across the Larch forest (Photo: B.Carlier); C - Overflow of the August 2015 debris flow on the Trois Arbres fan (Photo: K.Graff) 
ical situations, granular matrix debris flows can be triggered from the basin heads, setting into motion significant volumes of debris (Arnaud-Fassetta et al. 2005, Graff et al. 2016). For instance, during the June 2000 (R.I.-30 yr flood) event, about $12.000 \mathrm{~m}^{3}$ debris aggraded on the Peyronnelle fan (Einhorn 2003), a Peynin subcatchment (Fig. 4), while an additional, significant amount of material was then transferred along the Peynin River down to its junction with the Guil River, where important infrastructure damage took place (Arnaud-Fassetta et al. 2005, Fort et al. 2015) (Fig. 2). The volumes of sediment mobilized during the 100-year flood in 1957 have been estimated at $330.000 \mathrm{~m}^{3}$ (Koulinski 2000). Nevertheless, despite of high denudation rates observed on free faces located on the upstream parts of the catchment, an extreme rainfall event does not systematically imply a strong sedimentary response at the outlet.

\section{Methods}

In order to better assess the complex hydro-geomorphic dynamics of the Peynin catchment, we adopted three approaches:

1. Define the different components of the sediment cascade and the processes contributing to debris and water fluxes, with a special focus on the Peyronnelle first order catchment,

2. Use of passive tracers in the Peyronnelle catchment to measure the coarse bedload transport during rainfall-triggered, debris-flow events,

3. Develop a stock and flow modelling of sediment fluxes into the catchment.

This aims at a better assessment of sediment transport complexity from local to global scale induced by the diversity of geomorphic processes that takes turns in space and time.

\section{Sediment cascade}

The sediment cascade is now a rather classic concept, in which the various sediment stores and the processes that link them are represented (Chorley, Kennedy 1971, Caine 1974, Jones 2000, Schrott et al. 2003, Cossart 2016, Laute, Beylich 2016, Morche et al. 2016, Zwoliński 2016). Fieldwork allowed us to inventory the main sediment stores (or subsystems) of the Peynin catchment, as described in section 2, and to identify the different linkages between them (Fig. 5). Each link represents a geomorphic process (landslides, torrential stream, debris flow) that depletes sediment from one store to feed another one. Our previous experience (since 1995) in this area showed us that the functioning of the system is highly variable, both spatially and temporally. More specifically

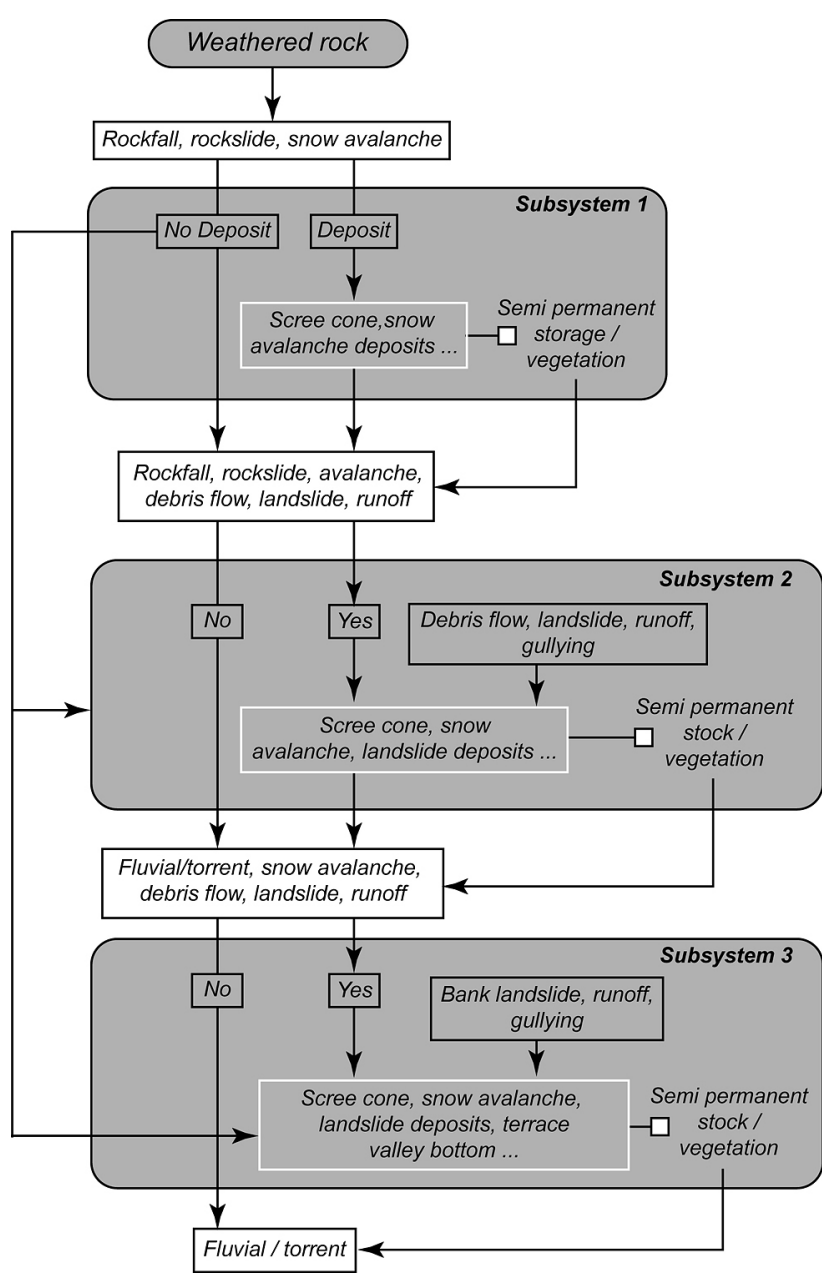

Fig. 5. Geomorphic cascade system in the Peynin catchment The Peyronnelle subcatchment is represented by subsystems 1 and 2 (modified from Cossart et al. 2018)

in the Peynin catchment, special attention was given to debris flow network, to know whether the material set into motion by a debris flow event remain either stored in the channel, or has aggraded on the torrential cone, or is exported out of the system.

\section{Measuring the bedload transport}

Several methods do exist to measure bedload transport, such as the collection of gravels in a retention basket, the use of piezoelectric bedload impact or geophone sensors (Rickenmann et al. 2012, 2014). To measure the specific transport during a debris-flow event, other techniques have been implemented, such as boulders marking with paint, introduction of magnets or radio transmitters in boulders, etc. But these techniques are not all effective depending on the given contexts of use, and on their cost (Rollet et al. 2008, Piegay et al. 2016). We eventually decide to use Passive Integrated Transponder (PIT) tags because of their relative cheap price which allowed us to increase their number in a context where the results obtained depend very much on the return rate 
of tracers, and more specifically on their depth in the channel, i.e. $<40 \mathrm{~cm}$ for the best results (Lamarre et al. 2005, Rollet et al. 2008).

Before setting the PIT tags in the Peyronnelle channel (summers 2013 and 2014), we tested the channel grain-size representativeness in order to better estimate the size of the transported bedload (Graff 2016). We installed directly 320 PIT tags in blocks/ boulders (long axis size varying from 9 -to- $50 \mathrm{~cm}$ ) belonging to the channel bank material. Ten injection sites were selected along the Peyronnelle thalweg (Fig. 6), according to different criteria such as: width of the channel, nature of channel material (alluvium and/or bedrock), pattern of the channel (linear, curved) and long profile. Each monitored particle (either block, boulder, or clast) was measured along its 3 axes (Long/Intermediate/Short). We injected about $30 \%$ of the PIT tags directly in the thalweg, and $70 \%$ were emplaced along the left and right banks within the channel or just over the top of the bank (Fig. 6B). A Differential Global Positioning System (DGPS) has been used to locate and map each monitored particles. The precision is estimated from $0.5 \mathrm{~m}$ for horizontal dimension to $1.5 \mathrm{~m}$ for vertical dimension.

Eventually, we tried to estimate the volumes of debris transported by the Peyronnelle during the August 2015 event. For this, we first estimated the average thickness of the debris flow deposit, in considering the maximum elevation reached by the flow (i.e. mud tracks left on the tree trunks) and the minimum elevation as represented by the height of the debris lobes. Second, we calculated the Peyronnelle fan area covered by debris flow lobes, and added the surface of the Peyronnelle channel. The volume is thus given by multiplying the average thickness by the surface of debris (Graff et al. 2018).

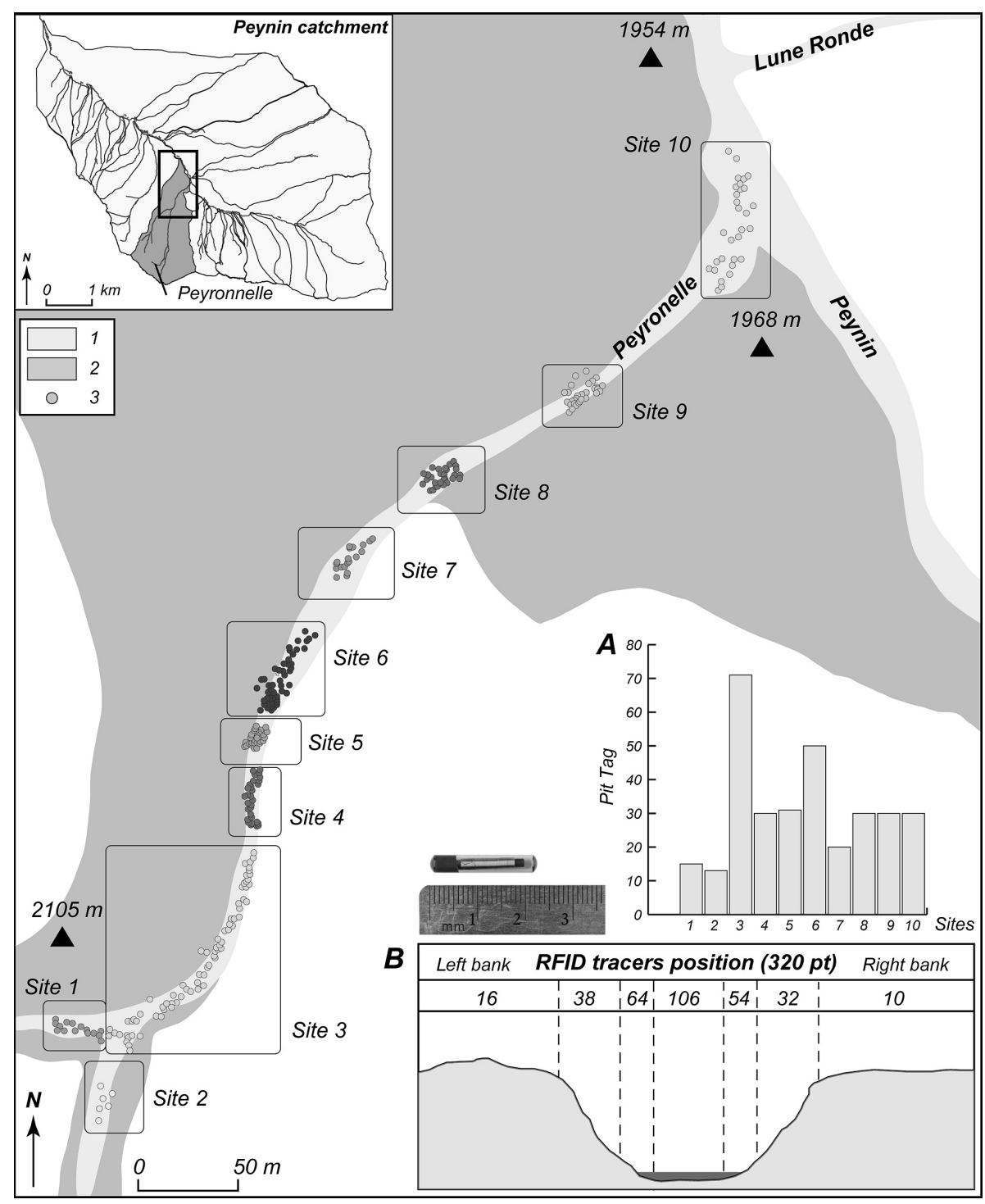

Fig. 6. Map of injection sites of Passive Integrated Transponders (PIT) tags along the Peyronnelle (320 pt) (adapted from Graff et al., 2018)

A - number of PIT tags injected for each site; B - specific initial injection positions and number of PIT tags in the Peyronnelle channel 
In addition, a meteorological station was implemented in 2014 on the right flank of the Peynin catchment, at $2000 \mathrm{~m}$ in elevation (Fig.1c). Rainfall were recorded every hour then have been computed for each day.

\section{Preliminary analysis of functional connectivity}

To complement the formalization of the sediment cascade and the analysis of debris flow sediment transport, we aim at exploring the complexity of sediment transfer into the Peynin catchment to understand how sediment export is generated at the outlet. Along the sediment cascade, sediments are transported by different geomorphic processes acting at different spatial and temporal scales. They define multiple relay processes that result in different patterns of sediment fluxes in the catchment.

Our objective is therefore to understand how the processes may be synchronized or desynchronized to generate sediment waves. This requires to document sediment availability into the catchment and the period during which the geomorphic processes are acting (duration, frequency, intensity) all along the sediment cascade. As a consequence, we adopted a more dynamic approach of sediment fluxes.

To better understand this complexity, a modelling procedure that considers the various compartments of the sediment cascade formalized in 3.1 is proposed. To simulate sediment dynamics into the catchment, we developed a Stock \& Flow Modelling based on System Dynamics (SD) using Vensim software. The entire sediment cascade is implemented in the Vensim simulation platform to create a stock and flow diagram (Cossart et al. 2018). It highlights the relationships among various variables (sediment stores and geomorphic processes) which have the potential to change over time according to a causal variable such as rainfall. This model provides a simulation to determine:

- the part of different geomorphic processes,

- the interaction between them as input/output agents, and between the compartments (sediment storage input/output/transfers between them).

As a consequence, the model has a longitudinal organization from upslope (contributing area) to downslope (source to sink) for a temporal analysis of sediment fluxes. It takes into account the availability of sediments within each sediment stores so that each sediment flux evolution corresponds to differential equation. This model is applied to estimate the required time for an optimal hydro-sedimentary functioning and to define the modalities of synchronization or desynchronization of all hydro-sedimentary pulses.

Theoretical data from literature and geomorphological expertise have been collected to characterize each geomorphic process in the model (rate and frequency). The model runs considering meteorological as a random effect. However, average precipitation rates and standard deviation are similar to the data observed at the meteorological station implemented in the catchment. The maximum rainfall value is estimated here according to historical event (1957 crisis) but other simulations were conducted considering higher rates. For more information about Vensim software, the design of the compartment model and the calibration data, we refer to Cossart et al. (2018).

\section{Results}

\section{Sediment Transit: debris flows dynamics along the Peyronnelle subcatchment}

Since the implementation of the meteorological station in 2014, no event has occurred until the August 8-9, 2015 (23 mm in $3 \mathrm{~h}$; intense storm cells). Debris flows have developed in the subcatchments of the left bank of the Peynin stream (Four à Chaux, Trois Arbres, Peyronnelle, Roche Rousse; Fig. 1c). Yet the rainfall event was spatially limited so that the flashflood regime did not extend to other Guil tributaries. A few days later, we could directly map in the field the debris flow surfaces that occurred in the PIT tags - monitored Peyronnelle subcatchment (Fig. 4) and record the PIT tags position by GPS.

Out of 320 pebbles and boulders initially equipped with PIT tags in this watershed, 101 have been recovered (i.e. $31 \%$ ) after the debris flow event and, among them, $90 \%$ out of the 101 were displaced (Fig. 7) (Graff 2016). Regarding the measurement of sediment transport, and compared to other methods used to characterize debris flows processes (geophone, Terrestrial Laser Scanning), the use of PIT tags for studying debris flows with muddy matrix is one original contribution of this work. Our return rate $(31 \%)$ is lower than those $(40-43 \%)$ obtained by other teams (Bel et al. 2015, Bel 2017) for debris flows with a granular matrix, as produced in crystalline or limestone massifs. Yet, as mentioned by Rollet et al. (2008), and even if the return rate is sometimes low, it is important to emphasize that particles are not completely lost. They can reappear during later follow-up events and be relocated, as it was the case during our observation period.

The longest, recorded travel distance exceeds 700 $m$ and more than a third of the PIT tags travelled over distances exceeding $300 \mathrm{~m}$. The left bank of the Peyronnelle torrent had a much greater activity (100 pebbles and boulders; $730 \mathrm{~m}$ displacement) than the right bank (20 pebbles and boulders; $60 \mathrm{~m}$ displacement) (Fig. 7B). Controlling factors are directly related to 


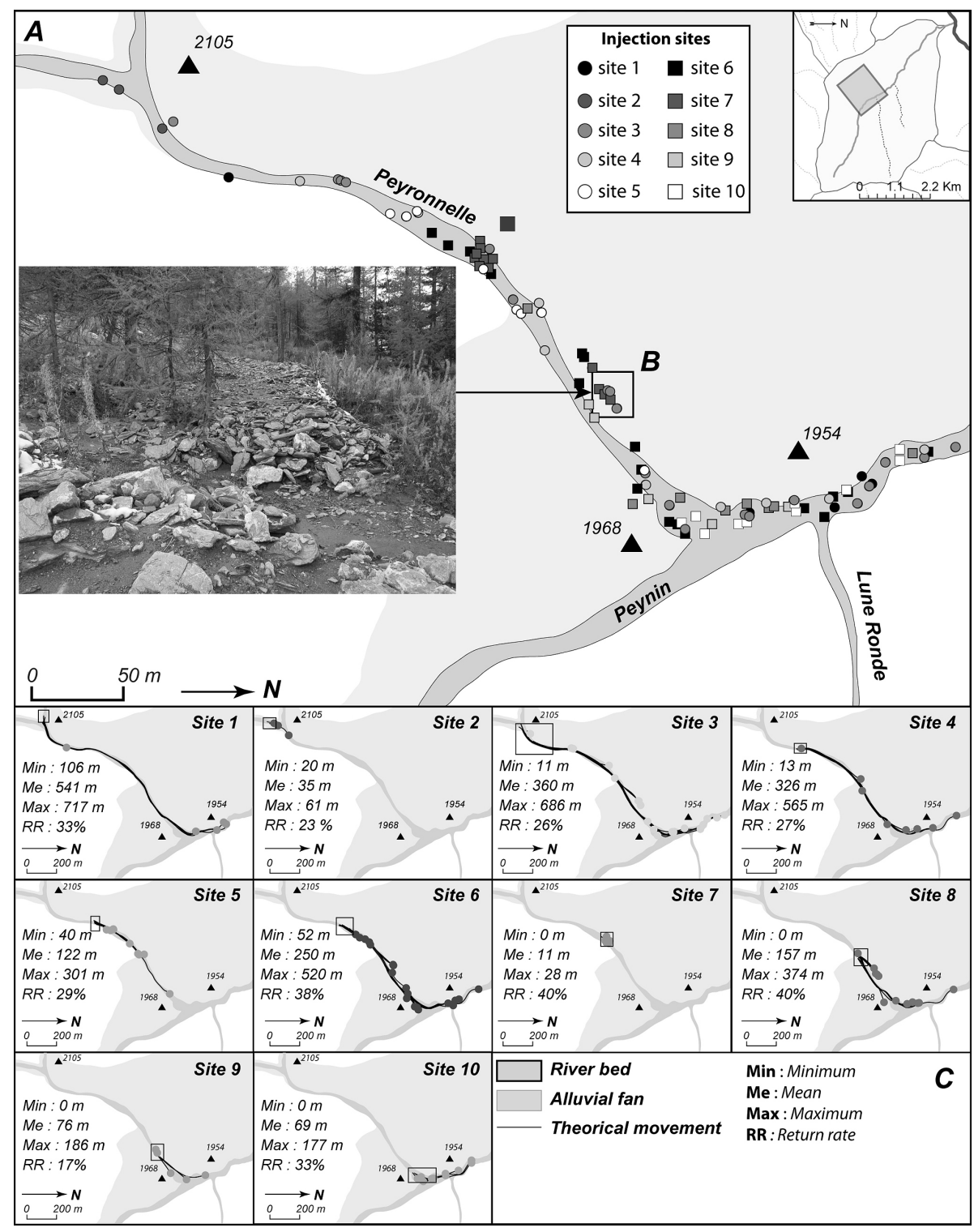

Fig. 7. Radio Frequency Identification (RFID) tracers' mobilization and transport during the August 8-9, 2015 event

A - 10 injection sites along the Peyronnelle channel; B - the Peyronnelle channel (see the square in A for location) close to its junction with the Peynin (Photo: K.Graff); C - analytical maps: theoretical measured displacements of recovered tracers from their initial injection sites (modified from Graff et al. 2018)

the steepness of the bed slope, allowing the displacement of the particles by gravity flow. More specifically, heights of the banks together with channel width regulated the acceleration of the debris flow.

We also compared the accumulation sites of Radio Frequency Identification (RFID) tracers vs. their initial injection site, so that we could classify pebbles and boulders equipped with PIT tags in 4 different groups (Fig. 8). The first group corresponds to PIT tags mobilized in, and redeposited downstream of the Peyronnelle channel (27 pebbles and boulders). The second group includes the PIT tags mobilized then deposited in preferential sites such as concave bends of the Peyronnelle (26 pebbles and boulders). The third group of PIT tags were found outside of the main channel zone, aggraded on the top of the
Peyronnelle fan (12 pebbles and boulders). But they still remained stored in the Peyronnelle catchment, in contrast with the last, fourth group, which corresponds to PIT tags that were displaced both outside the main Peyronnelle channel and catchment (36 pebbles and boulders, representing $36 \%$ of the total PIT tags), and joined the main Peynin torrential stream. This last group clearly represents an output from the semi-permanent sediment store represented by the Peyronnelle fan.

We also tried to compare the transfer distance of PIT tags recovered with the grain size (B-axis) for each depositional zone, but any significant correlation between the two variables could not be found $\left(\mathrm{r}^{2}=0.077\right)$. Similarly, we did not find any significant correlation between distances travelled and granular- 


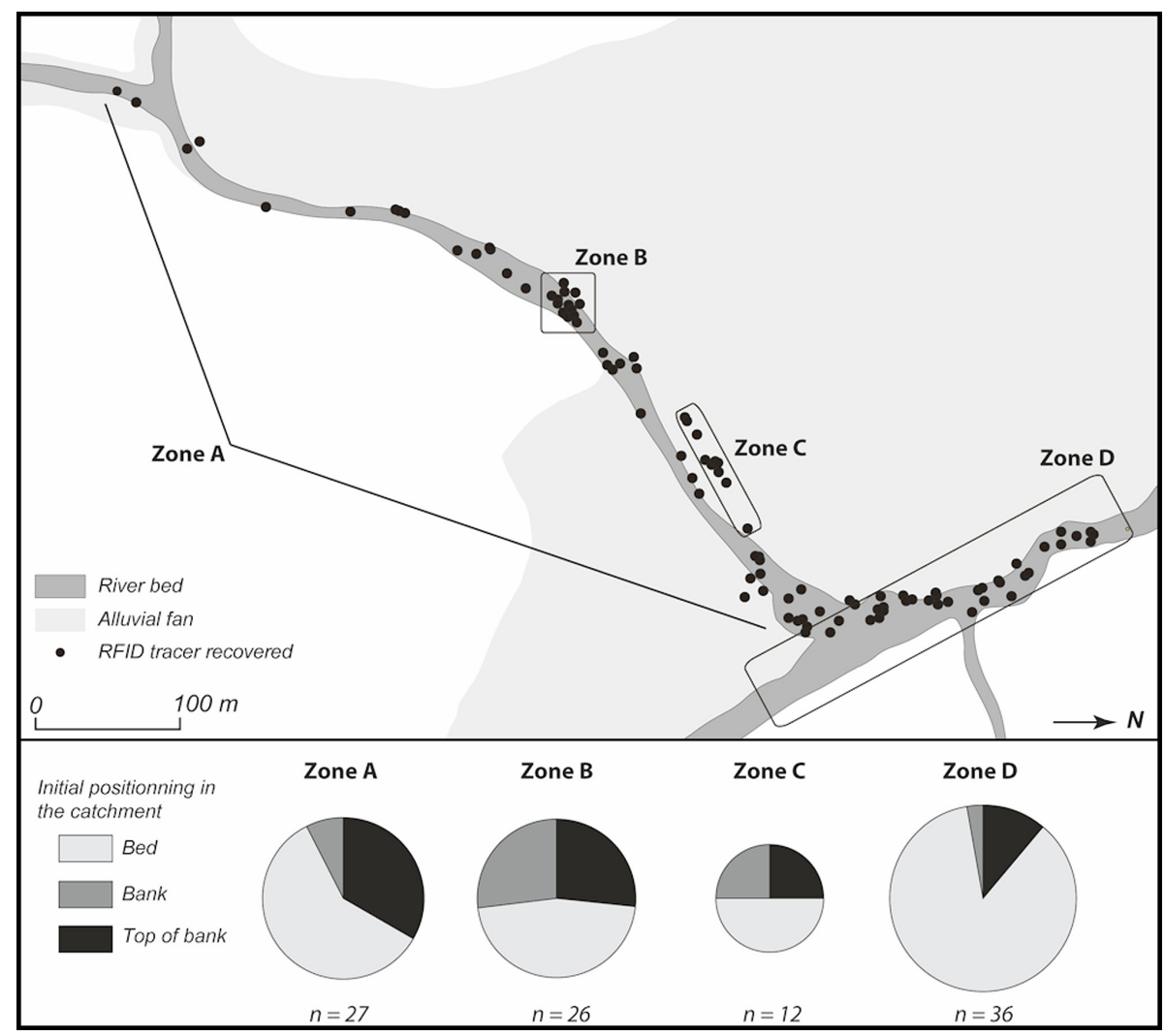

Fig. 8. Localisation of the four main deposition sites/zones

ity of the sediment load. It means that coarse blocks are mobilized in the same way as small blocks, pebbles, gravels or fine sediments, as in a cohesive debris flow (Graff 2016).

Our estimate of the volume of debris transported by the Peyronnelle debris flows during the August 8-9, 2015 event is as follows (Graff et al. 2018):

- average thickness of the debris flow deposit: 0.71 $\mathrm{m}$,

- area of debris flow deposits on the Peyronnelle fan and channel: $12,789 \mathrm{~m}^{2}$,

- total volume mobilized by the Peyronnelle debris flows: $9,100 \mathrm{~m}^{3}$.

In addition, we also considered the $36 \%$ of debris that flowed out of the Peyronnelle catchment (this would correspond to a volume of $3,240 \mathrm{~m}^{3}$ ) and joined the Peynin torrential stream, so that the total volumes mobilized would represent a minimum of $12,240 \mathrm{~m}^{3}$.

These results, compared with those obtained after the 2000 debris-flow event, i.e. a minimum of 12,000 $\mathrm{m}^{3}$ debris aggradation on the Peyronnelle fan (Einhorn 2003, Arnaud-Fassetta et al. 2005), highlight the rapid sedimentary recharge of first order drains in elementary basins allowing frequent mobilization of stocks through debris flows, even during meteorological events of relatively moderate intensity. They also confirm the pulsating character of these sediment fluxes, hence the strongest functionality of de- bris-flow dominated channels in the Peynin/Peyronnelle catchments (Fort et al. 2002, Arnaud-Fassetta et al. 2005, Graff et al. 2018).

\section{Simulation results}

The simulation clearly highlights several erosion processes acting as major agent in the sediment transfer, such as debris flow. Their frequency and sediment transport capacity induce an efficient connectivity between sediment stores (such as screes), in the initiation of the hydrological network, and the main channel of the Peynin river. However, the results of the simulation also underline a complex pattern of sediment dynamics into the Peynin catchment. From one meteorological event to another, the sediment cascade can be alternatively partially or fully activated in an efficient way (Fig. 9). If an intense meteorological forcing generally induces debris flow, it does not guarantee important sediment export from the catchment.

The geomorphic processes, which vary over time (as expressed in Fig. 9: duration, frequency, but also intensity), can explain the partial functioning of the sediment cascade. Nevertheless, results of the simulation also highlight the role of the synchronicity of the various variables and especially between sediment waves and hydro-meteorological pulses (Fig. 9). This synchronicity is not continuous over time, 


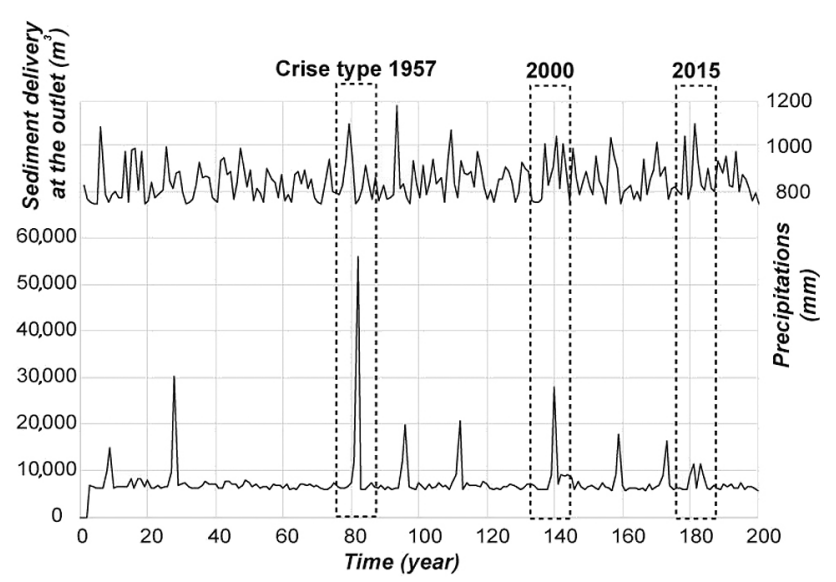

Fig. 9. Comparison between meteorological events and sediment fluxes observed at the outlet of the Peynin River catchment using results from simulation in Vensim platform

mainly because of sediment stores availability. For comparable rainfall events, several sediment pulses can be considered as major geomorphological crisis (such as 1957 and 2000 events) separated by minor, less morphogenic crisis (such as the 2015 event) (Fig. 9). This underlines the sediment delivery unsteadiness along the sediment cascade. After main events (such as 1957), sediment stores are exhausted. For the following events, sediment fluxes are therefore limited until a sufficient volume of sediments is available. As a consequence, the flood impact in the sediment fluxes is highly correlated to the initial state of the sediments storages. When the sediment storages are filled enough, the system is mature and can be efficiently stimulated: the stores can supply sediments to the sink, even in the case of a low magnitude hydrometeorological event. In the case of the Peynin catchment, we can consider a period of almost 80 years for an optimal reconstruction of sediment storages. This duration corresponds to the time necessary to efficiently combine all the geomorphic processes to progressively impede the various compartments of the cascade. Consequently, a sediment wave observed at the outlet of the catchment can be explained firstly by an extreme hydrological event, but also by secondly a lower one in a context of mature stores all along the sediment cascade.

\section{Discussion}

In the Peynin catchment, there is a significant variability in sediment delivery from a tributary to another one. The upstream part of the catchment, where sediment stores are the most important, is almost totally disconnected from the outlet because flows are not enough concentrated. In fact, the de- bris volumes, mostly supplied by the remobilization of former channel deposits of the left bank subcatchments, allow a sporadic, yet systematic supply to the sedimentary fluxes joining the Peynin channel. This in turn contributes strongly to direct inputs of fine and coarse sediments down to the outlet, i.e. the Guil River at Aiguilles village. During generalized events (e.g. floods of 1957 and 2000), some sediments were directly set into motion by the Peynin torrent, which was fed by additional material provided by bank erosion and gravitational processes, before reaching its junction, torrential fan at Aiguilles village (Fig. 2). During the last 20 years, the Peyronnelle and Three Arbres subcatchments $\left(<2 \mathrm{~km}^{2}\right.$, representing $<15 \%$ of the Peynin catchment area) have exported at least $80 \%$ of the sediments observed at the outlet. The total volumes supplied to the Peynin channel were estimated to $170,000 \mathrm{~m}^{3}$, those stored to $133,000 \mathrm{~m}^{3}$ (78\%) and those exported downstream to $37,000 \mathrm{~m}^{3}$ (22\%) (Viel et al. 2018). Our results therefore show the major role played by the debris and torrential flows in the efficiency of the lower part of the sediment cascade of the Peynin River. Thus, to be efficient, the sedimentary cascade requires not only high erosion rates, but also an important connectivity between sediment erosion area, sediment store and the main channel of the catchment.

As our results demonstrate, several factors can influence the sediment connectivity and induce a complex pattern of sedimentary flows. In the Peynin catchment, few geomorphological agents induce a direct transfer to the outlet. To be efficient, geomorphic agents have to be linked in space and time all along the sediment cascade. These relays are efficiently organized on the left bank of the Peynin River whereas in the Fond de Peynin cirque, few processes are able to transport sediments from the screes to the main channel. Sediment availability also appears as another significant triggering factor of the unsteadiness of sediment fluxes. Along the sediment cascade, stores are exhausted after main events. As a consequence, sediment fluxes remain very low until a significant volume of sediment available is reached again. Debris flow processes in the Peyronnelle and Trois Arbres subcatchments induce an important sediment supply which allows the sediment cascade to be more rapidly efficient than in the rest of the catchment. This is reinforced by the location of the two large cones of the Peyronnelle and Trois Arbres: they constitute another sediment input area which can contribute to sediment supply into the main channel of the Peynin. These two small catchments thus combine several factors making efficient the sediment cascade: significant erosion processes (i), geomorphic processes well organized in space and time to transport sediments toward the main channel (ii) and sediment availability rapidly recovered after a meteorological 
event (iii). The downstream part of the Peynin River is therefore more sensitive to high sediment transfer in case of a significant hydro-climatic event.

The debris influxes to the Guil River are those going to generate significant damages to infrastructure and population during abundant, intense rainfall events, as observed after the June 2000 event (Einhorn 2003, Arnaud-Fassetta et al. 2005, Fort et al. 2015). Despite the low density of permanent population $\left(<5\right.$ inhabitants per $\left.\mathrm{km}^{2}\right)$, the tourism activities during summer and winter holidays (when the resident population can be multiplied by a factor of 10) have led to a concentration of human stakeholders in areas particularly exposed to debris floods hazards, such as the Peynin outlet (Arnaud-Fassetta, Fort 2004, Carlier et al. 2018b).

This risk management issue particularly raises the question of sediment supply evolutions at the outlet of the Peynin, in a context of global changes. Intergovernmental Panel on Climate Change's scenarios suggest an increase in the frequency of High Magnitude and Low Frequency (HMLF) meteorological events for the next 100 years and an increase of the temperatures inducing less snow and more rain in the catchment (IPCC, 2012). This would indicate more frequent floods events and a better coupling between geomorphic agents in space and time, inducing a more efficient sediment cascade. Without an increase in shale erosion, a part of sediment stores could be purged and sediment availability could be reduced. However, the large amount of sediments stored in the Peyronnelle and Trois Arbres cones should be able to feed sediment to the downstream part of the catchment and therefore maintain important sediment fluxes to the outlet, on the Peynin cone. As a consequence, the increase in HMLF events should result in an increase of sediments fluxes observed at the outlet and as a result more damaging events to come even if the sediment delivery from these complex combinations of processes remains difficult to predict.

This is particularly worrying in view of the vulnerability analyses carried out in the Aiguilles village. Social and physical vulnerabilities were combined to estimate the potential consequences of increasing flash-floods events (in both frequency and magnitude) in a context of climate and land use change, such as the extent of warehouses, or small business industrial park (Carlier et al. 2018b). Results provided by Carlier et al. (2018b) show that the Aiguilles community has more dependent people to care for (i.e. hospital, school) than in other village communities. In addition, Aiguilles' inhabitants have a lack of information on flood risks so that they tend to underestimate the danger represented by floods, despite the events of the last 60 years $(1957,2000$, 2002, 2008 and 2011; PNRQ 2016).

\section{Conclusion}

We tried to better understand the unsteadiness of sediment fluxes at the outlet of the Peynin river catchment, a typical feature of mountainous basin in the Southern Alps. We have set up a three-step method consisting in formalising the sediment cascade (i), analysing the debris flows sediment transport using RFID tracers (ii), and simulating the sedimentary fluxes using a stock and flow modelling to better understand the progressive construction of the sediment wave in the catchment.

Our results highlight the role of connectivity within catchment to export large amount of sediment at the outlet. It brings interesting elements to understand relay processes within the sediment cascade. The efficiency of these relays, highly variable in space and time, can significantly vary in a catchment. Less than $15 \%$ of the catchment area (Peyronnelle and Trois Arbres subcatchments) generate more than $80 \%$ of sedimentary flows at the outlet of the Peynin. This major contribution essentially is permitted by debris flow processes that can transport large quantities of sediments from erosion area to the main channel and feed sediment stores in the downstream part of the sediment cascade. As a consequence, our results underline that sediment variability at the catchment outlet depends on sediment availability and on the frequency/magnitude of meteorological events that can activate subparts of the entire sediment cascade in an efficient way. A high magnitude and low frequency hydro-meteorological event occurring on mature sediment stores (high sediment availability) can indeed generate a simultaneous activation of sediment transfer within the components of the sediment cascade, and finally, a sediment wave at the outlet. Recent climate trends suggest more damaging events to come, in relation to more extreme events (rain-storms, snow-storms followed by rapid melting). Nevertheless, the sediment delivery associated to the complex pattern of the sediment cascade remains difficult to estimate in the future even though this is an essential issue in risk mitigation.

\section{Acknowledgments}

This research is part of the program ANR 12 - SENV0004, SAMCO (Adaptation of the Society to Mountain risks in a Context of Global Change); we would like to acknowledge with thanks the ANR researchers working in this program and all the collaborators (BRGM, IPGS, IRSTEA, LIVE-UMR7362, PRODIGUMR8586, GEODE-UMR5602 and GEO-HYD) for their material, financial and intellectual support. We also would like to thank the Queyras Regional Nature Park for its support, especially Bérengère Charnay (Water and Natural Risks Project Manager). 
Finally, our warm appreciation goes to the two unknown reviewers, and to the organizers of the 1rst DENUCHANGE Workshop: Achim Beylich, Joanna Gudowicz, and Zbigniew Zwoliński, for their wonderful welcome and support during the preparation of our contribution.

\section{Author's contribution}

V.V., CL, M.F. and G.A-F. designed the study; V.V., KG, M.F., B.C., C.L., G.A-F and M.M. carried out the fieldwork and field data acquisition; V.V., KG., C.L. and E.C. processed data; V.V., M.F., and C.L. wrote the manuscript with inputs from all co-authors.

\section{References}

Arnaud-Fassetta G., Cossart E., Fort M., 2005. Hydro-geomorphic hazards and impact of man-made structures during the catastrophic flood of June 2000 in the Upper Guil catchment (Queyras, Southern French Alps). Geomorphology 66: 41-67.

Arnaud-Fassetta G., Fort M., 2004. La part respective des facteurs hydro-climatiques et anthropiques dans l'évolution récente (1956-2000) de la bande active du Haut-Guil, Queyras, Alpes françaises du Sud. Géosystèmes méditerranéens et montagnards, Un mélange offert à Maurice Jorda, Méditerranée, 1-2, 143-156. DOI: 10.3406/medit.2004.3350, 2004.

Arnaud-Fassetta G., Fort M., 2014. Hydro-bio-morphological changes and control factors of an upper Alpine valley bottom since the mid-19th century. Case study of the Guil River, Durance catchment, southern French Alps. In: J.M.Carozza, B.Devillers, N.Marriner, C.Morhange (eds), The Little Ice Age in the Mediterranean. Méditerranée 122: 159-182.

Bel C., 2017. Analysis of debris-low occurrence in active catchments of the French Alps using monitoring stations. Doctorate PhD Thesis, Université Grenoble-Alpes.

Bel C., Navratil O., Liébault F., Fontaine F., Bellot H., Laigle D., 2015. Monitoring Debris Flow Propagation in Steep Erodible Channels. In: G.Lollino, M.Arattano, M.Rinaldi, O.Giustolisi, J.-C.Marechal, G.E.Grant (eds), Engineering Geology for Society and Territory - Vol. 3, Springer International Publishing Switzerland, Ch. 20: 103-108. DOI: 10.1007/978-3-319-090542_20.

Beniston M., 2003. Climatic change in mountain regions: a review of possible impacts. Climatic Change 59: 5-31.

Beniston M., 2005. The risks associated with climatic change in mountain regions. In: U.Huber, H.Bugmann, M.Reasoner (eds), Global change and mountain regions: an overview of current knowledge. Springer, Dordrecht: 511-520.

Beniston M., Stoffel M., 2013. Assessing the impacts of climatic change on mountain water resources. Science of The Total Environment 493: 1129-1137. DOI: 10.1016/j.scitotenv.2013.11.122.

Brardinoni F., Mao L., Recking A., Rickenmann D., Turowski J.M., 2015. Morphodynamics of steep mountain channels. Earth Surface Processes and Landforms 40: 1560-1562.

Caine N., 1974. The geomorphic processes of the Alpine environment. In: J.D.Ives, R.G.Barry (eds), Arctic and Alpine Environment. Methuen, London: 721-748.

Carlier B., Carlier G., Gance J., Provost F., Lissak C., Graff K., Viel V., Fort M., Cossart E., Bétard F., Madelin M., Malet J.-P., Arnaud-Fassetta G., 2018a. Distribution spatiale et quantification des stocks sédimentaires d'un petit bassin-versant alpin: l'exemple du Peynin (Queyras, Alpes du Sud). Géomorphologie: relief, processus, environnement 24(1): 59-76. DOI: 10.4000/ geomorphologie.11994.

Carlier B., Puissant A., Dujarric C., Arnaud-Fassetta G., 2018b. Upgrading of an index-oriented methodology for consequence analysis of natural hazards: application to the Upper Guil catchment (southern French Alps). Natural Hazards and Earth System Sciences 18: 2221-2239. DOI: 10.5194/nhess-18-2221-2018.

Chorley R.J., Kennedy B.A., 1971. Physical geography: a systems approach. Prentice-Hall International, London.

Cossart E., 2016. L'(in)efficacité géomorphologique des cascades sédimentaires en question: les apports d'une analyse réseau. Cybergeo: European Journal of Geography [Online], Systèmes, Modélisation, Géostatistiques, document 778. DOI: 10.4000/ cybergeo.27625 30/08/2017 22:27.

Cossart E., Fort M., 2008. Sediment release and storage in early deglaciated areas: Towards an application of the exhaustion model from the case of Massif des Écrins French Alps since the Little Ice Age. Norsk Geografisk Tidsskrift - Norwegian Journal of Geography 62: 115-131. DOI: 10.1080/00291950802095145.

Cossart E., Viel V., Lissak C., Reulier R., Fressard M., Delahaye D., 2018. How might sediment connectivity change in space and time? Land Degradradation and Development 29(8) 25952613. DOI: $10.1002 / \mathrm{ldr} .3022$.

Einhorn B., 2003. Budget sédimentaire d'un bassin-versant torrentiel des Alpes du Sud: le haut Guil (Queyras, Hautes Alpes). Master's Thesis, Université Paris 7, Diderot.

Fort M., 2015. Impact of climate change on mountain environment dynamics. Journal of Alpine Research | Revue de Géographie Alpine [Online], 103-2 | 2015 DOI: 10.4000/rga.2877.

Fort M., Arnaud-Fassetta G., Bétard F., Cossart E., Geai M.-L., Madelin M., Bouccara F., Carlier B., Sourdot G., Tassel A., Bletterie X., Charnay B., 2015. Sediment dynamics and channel adjustments following torrential floods in an upper alpine valley (Guil river, Southern French Alps). In: G. Lollino, M.Arattano, M.Rinaldi, O.Giustolisi, J.-C.Marechal, G.E.Grant (eds), Engineering Geology for Society and Territory - Vol. 3, Springer International Publishing Switzerland, Ch. 65: 313-318. DOI: 10.1007/978-3-319-09054-2 65

Fort M., Arnaud-Fassetta G., Cossart E., Beaudouin B., Bourbon C., Debail B., Einhorn B., 2002. Impacts et signification hydromorphologique de la crue du Guil de Juin 2000 (Haut Queyras). In: D.Delahaye, F.Levoy, O.Maquaire (eds), Geomorphology: from Expert Opinion to Modelling. A tribute to Professor JeanClaude Flageollet. CERG Editions, Strasbourg: 159-166.

Graff K., 2016. Contribution des laves torrentielles dans un petit bassin versant montagnard. L'exemple du sous-bassin versant de la Peyronnelle (Queyras-France). DYNARISK Master's Thesis, University Paris-Diderot, Sorbonne-Paris-Cité.

Graff K., Viel V., Carlier B., Lissak C., Arnaud-Fassetta G., Fort M., Madelin M., 2016. Sediment tracing from small torrential channels to gravel-bed rivers using PIT tags method. A case study from the upper Guil catchment. Geophysical Research Abstracts, 18, EGU2016-8100-1.

Graff K., Viel V., Carlier B., Lissak C., Madelin M., Arnaud-Fassetta G., Fort M., 2018. Traçage sédimentaire des laves torrentielles dans le bassin de la Peyronnelle (Queyras, Alpes françaises du Sud). Géomorphologie: relief, processus, environnement 24(1): 43-57. DOI: 10.4000/geomorphologie.11967.

Grandjean G., Thomas L., Bernardie S., The SAMCO Team, 2018. A Novel Multi-Risk Assessment Web-Tool for Evaluating Future Impacts of Global Change in Mountainous Areas. Climate 6(4) 92. DOI: $10.3390 /$ cli6040092.

Heckmann T., Vött A., Haas F., Becht M., 2016. Geomorphic process-response systems on different time scales. Zeitschrift für Geomorphologie, Supplementbände 60(1): 1-3.

IPCC [Intergovernmental Panel on Climate Change], 2012. Managing the Risks of Extreme Events and Disasters to Advance Climate Change Adaptation, A Special Report of Working Groups I and II of the Intergovernmental Panel on Climate Change [Field C.B., Barros V., Stocker T.F., Qin D., Dokken D.J., Ebi K.L., Mastrandrea M.D., Mach K.J., Plattner G.K., Allen S.K., Tignor M., Midgley P.M. (eds)], Cambridge University Press, Cambridge, UK, and New York, NY, USA.

Jones A.P., 2000. Late quaternary sediment sources, storage and transfers within mountain basins using clast lithological anal- 
ysis: Pineta Basin, central Pyrenees, Spain. Geomorphology 34(3-4): 145-161. DOI: 10.1016/S0169-555X(00)00004-0.

Jordan P., Slaymaker O., 1991. Holocene sediment production in Lillooet River basin: a sediment budget approach. Géographie physique et Quaternaire 45: 45-57.

Koulinski V., 2000. Étude hydraulique du torrent du Peynin sur son cône de déjection. Unpublished Report, Commune d'Aiguilles.

Lamarre H., MacVicar B., Roy A., 2005. Using Passive Intergrated Transpondeur (PIT) tags to investigate sediment transport in gravel-bed rivers. Journal of Sedimentary Research 75: 736-741.

Laute K., Beylich A.A., 2016. Sediment delivery from headwater slope systems and relief development in steep mountain valleys in western Norway. In: A.A.Beylich, J.C.Dixon, Zb.Zwoliński (eds), Source-to-Sink Fluxes in Undisturbed Cold Environments. Cambridge University Press, United Kingdom, Ch. 21: 293-312. DOI: 10.1017/CBO9781107705791.022.

Lemoine P., de Gracianski P.-C., Tricart P., 2000. De l'océan à la chaîne de montagnes: Tectonique des plaques dans les Alpes. Gordon and Breach, Paris.

Lissak C., Fort M., Arnaud-Fassetta G., Viel V., Carlier B., 2015. Typology of potential high contribution areas in the sediment budget in the Upper Guil Catchment (Queyras, French Alps). Geophysical Research Abstracts, 17, EGU2015-4915-2

Morche D., Krautblatter M., Heckmann T., Haas F., Götz J., 2016. Rates of slope and channel processes in the Reintal valley, Bavarian Alps. In: A.A.Beylich, J.C.Dixon, Zb.Zwoliński (eds), Source-to-Sink Fluxes in Undisturbed Cold Environments. Cambridge University Press, United Kingdom, Ch. 24: 351363. DOI: $10.1017 /$ CBO9781107705791.025.

Piégay H., Arnaud F., Cassel M., Depret T., Alber A., Michel K., Rollet A. J., Vaudor L., 2016. Suivi par RFID de la mobilité des galets: retour sur 10 ans d'expérience en grandes rivières. Bulletin de la Société Géographique de Liège 67: 77-91.

PNRQ [Parc Naturel Régional du Queyras], 2016. Diagnostic de vulnérabilité du bassin versant du Guil aux inondations, Final Report, April 2016: 1-48.

Rickenmann D., Turowski J.M., Fritschi B., Klaiber A., Ludwig A. 2012. Bedload transport measurements at the Erlenbach stream with geophones and automated basket samplers. Earth Surface Processes and Landforms 37(9): 1000-1011. DOI: 10.1002/ esp.3225.

Rickenmann D., Turowski J.M., Fritschi B., Wyss C., Laronne J.B., Barzilai R., Reid I., Kreisler A., Aigner J., Habersack H., 2014. Bedload transport measurements with impact plate geophones: comparison of sensor calibration at different gravel-bed streams. Earth Surface Processes and Landforms 39(7): 928-942. DOI 10.1002/esp.3499.

Rollet A.-J., Macvicar B., Piégay H., Roy A., 2008. Utilisation de transpondeurs passifs pour l'estimation du transport sédimentaire: premiers retours d'expérience. La Houille Blanche. Revue internationale de l'eau, EDP Sciences.

Schrott L., Hufschmidt G., Hankammer M., Hoffmann T., Dikau R., 2003. Spatial distribution of sediment storage types and quantification of valley fill deposits in an alpine basin, Reintal, Bavarian Alps, Germany. Geomorphology 55: 45-63. DOI 10.1016/S0169-555X(03)00131-4.

Slaymaker O., 1977. Estimation of sediment yield in temperate alpine environments. In: Erosion and Solid Matter Transport in Inland Waters Proc. Paris Symposium, IAHS-AISH Publication 122: 109-117.

Slaymaker O., 2003. The sediment budget as conceptual framework and management tool. Hydrobiologia 494: 71-82.

Tricart J., 1958. Étude de la crue de la mi-Juin 1957 dans la vallée du Guil, de l'Ubaye et de la Cerveyrette. Revue de Géographie Alpine 4: 565-627.

Tricart J., 1961. Mécanismes normaux et phénomènes catastrophiques dans l'évolution des versants du bassin du Guil (Hautes-Alpes France). Zeitschrift für Geomorphologie 5: 277301.

Tricart P., 1980. Tectonique superposée dans les Alpes occidentales au Sud du Pelvoux; Évolution structurale d'une chaîne de collision. Unpublished Habilitation Thesis, Strasbourg University.

Tricart P., Schwartz S., Lardeaux J.-M., Thouvenot F., Du Chaffaut S.A., 2004. Carte géologique de la France à 1:50 000. 848, Aiguilles-Col Saint-Martin. BRGM, Orléans.

Viel V., Graff K., Carlier B., Lissak C., Cossart E., Arnaud-Fassetta G., Madelin M., Fort M., 2018. Debris-flow functioning and their contribution to sedimentary budget: the Peyronnelle subcatchment of the Guil River (Upper Queyras, Southern French Alps). In: J.Gudowicz, A.A.Beylich, Zb.Zwoliński (eds), Denudation and Environmental Changes in Different Morphoclimatic Zones, Book of Abstracts, 1st Workshop of the IAG/ AIG Working Group DENUCHANGE, Storkowo-Szczecinek (Poland), September 25-27: 25-26.

Zwoliński Zb., 2016. Solute and solid cascade system in the Antarctic oases. In: A.A.Beylich, J.C.Dixon, Zb.Zwoliński (eds), Source-to-Sink Fluxes in Undisturbed Cold Environments. Cambridge University Press, United Kingdom, Ch. 15: 183198. DOI: 10.1017/CBO9781107705791.016. 